\title{
Government Ownership and Value of Listed Firms in Kenya: A Panel Data Evidence
}

\section{Fredrick Onyango Odhiambo ${ }^{1 *}$, Nixon Oduor Omindi ${ }^{2}$}

${ }^{1}$ Senior Researcher, Department of Research Monitoring \& Evaluations, Research Pro Solutions, P.O. Box 102609-00101 Nairobi, KENYA

${ }^{2}$ Assurance Director, Department of Finance and Administration, Bukas Consultancy, P.O. Box 102558-00101 Nairobi, KENYA

*E-mail for correspondence: ombako82@gmail.com

Cell Phone: +254721977108

Received: Jun 1, 2015;

Accepted: Jun 29, 2015;

Published: Jul 24, 2015

Source of Support: Nil

No Conflict of Interest: Declared

\begin{abstract}
This study examines the relationship between government ownership and performance of listed firms on the Nairobi Securities Exchange. The quadratic term of government ownership is included in the model to test for the effect of increasing government ownership levels on performance. We use panel data techniques on 102 firm-year observations between 2003 and 2013 for all the listed firms in which the government directly owns some shares. We find no relationship between government ownership and performance at lower levels of government ownership. We find a negative relationship between government ownership and performance at higher levels of government ownership. We estimate, through differentiation of the Tobin's $Q$ model, that government ownership has a negative effect on performance when government ownership exceeds $41 \%$. The study concludes that lower government ownership levels do not affect firm performance but as the ownership rises, government ownership has a detrimental effect on firm performance. We provide implications of these results for policy and practice.
\end{abstract}

Keywords: Government Ownership, Performance, Nairobi Securities Exchange, Panel Data JEL Classifications Code: G34

\section{INTRODUCTION}

Government ownership in firms has been a heated debate among scholars over the past decade just as much as has been the debate on the role of corporate governance in firm performance. Since the classical paper by Fama and Jensen (1983), effective corporate governance has been taunted over the years as a significant determinant of firm success. It reduces agency costs enabling firms to operate with maximum efficiency and achieve economies of scale. While scholars agree that institutional investors are important to firms as they contribute to effective monitoring (Choi et al. 2012), the government has been regarded as an unconventional institutional investor who differs from the rest of the institutional investors (Saleh et al. 2009). The government as an institutional investor has, therefore, been researched by some scholars to determine whether government ownership adds value to a firm or whether the presence of government ownership is detrimental to the performance of firms.

Most of the studies on government ownership and performance relationship have not focused on Kenya as a developing country despite the importance of Kenya as a business hub for the East and Central Africa Region. The Government of Kenya has also been divesting its equity from corporate organisations it previously fully owned through privatisation of some of the parastatals such as Kenya Airways. Thus, the Government of Kenya has been actively selling off its shares to the public through initial public offers (IPOs) as was the case with Kenya Electricity Generating Company (KENGEN) and Kenya Reinsurance Company in 2006 and Safaricom in 2008, among other IPOs. Further, it has been diluting it control in most of the listed firms. For instance, the Government of Kenya initially had a $7.32 \%$ share ownership in Housing Finance (HF) [formally Housing Finance Corporation of Kenya (HFCK)], until 2007 when it loosened its grip to a paltry $3.66 \%$. This scenario is replicated with government shareholding in Kenya Commercial Bank (KCB) and Mumias Sugar Ltd. In some cases, the Government of Kenya has increased its control. For example, the government now owns $50 \%$ of the shares in Kenya Power and Lighting Company (KPLC) up from a shareholding of $40.44 \%$ back in 2010 . The same scenario is played out in KENGEN where the government now owns $70 \%$ of equity up from $40.42 \%$ in 2004 . The government of Kenya is increasing its ownership in strategic industries like energy while divesting in other industries like banking and telecommunication. 
While there are a plethora of studies on the effects of government ownership in firms, there is still no consensus on how it affects firm performance as empirical results have provided mixed results. Studies have found positive, negative, U-shaped, inverted U-shaped, or no relationship between government ownership and firm performance. Jiang et al (2008) found that government ownership had a positive impact on firm performance in China. Yu (2013) and Hess et al., 2004) found a U-shaped relationship between government ownership and firm performance in China while Sun et al. (2002) found that government ownership had an inverted U-shaped relationship with firm performance. On the other hand, scholars such as Alfaraigh et al. (2012), Ongore and K'Obonyo (2011), and Kiruri (2013) found that government ownership was negatively related with firm performance. Further, there are a few studies that have found no relationship at all between government ownership and firm performance (Hovey et al. 2003, Saleh et al., 2009; Choi et al., 2012).

As much as these studies are important in establishing the relationship between government ownership and firm performance, most of them are focused on a contextually different market from the Kenyan market and, therefore, the results may not apply to Kenya. For those that focused on Kenya, they majorly suffer from methodological designs are they are mostly cross-sectional surveys conducted at one point in time. So far, none of the studies on Kenya used secondary data, and more specifically a panel data, to examine the effect of government ownership on firm performance. The inconsistencies in empirical results on the relationship between government ownership and firm performance, problems with ownership classification (where government ownership is bundled as both government shareholding and marketized corporate shareholding) and design flaws in some of the studies especially those that employ the use of surveys motivate the present study. To address the gaps in the literature on government ownership and performance in Kenya, this study examines how the proportion of government shareholding in publicly listed firms influence their performance.

We employ panel data techniques to analyse data and reveal that government ownership has a negative effect on firm performance especially at higher levels of ownership but no effect at lower levels of ownership. We explain why this is the case. This paper is organised as follows. The next section reviews pertinent literature on the relationship between government ownership and firm performance. We discuss some theories related to this subject and also review some empirical studies in this area. Section III is a detailed explanation of the study methodology adopted. Section IV presents the empirical analysis while Section V provides the main results. Section VI concludes.

\section{LITERATURE REVIEW}

\section{Corporate Governance Theories}

Government ownership is usually regarded as being inefficient. This is usually explained through property rights and residual claimant theory. The property rights theory claims that the rights in the public sector are not as clearly defined as those in the private sector. Thus, public owners lack an incentive to seek profits. They do not, therefore, effectively monitor management performance (Yu, 2013).

The residual claimant theory asserts that in addition to shareholders, employees suffer a residual risk that arises due to specific investments, which present a valid and legitimate basis for residual claims. Employees are, therefore, residual claimants as their income depends upon a hazardous quasi-rent (Brink, 2010).

Another theory that can be used to explain the relationship between government ownership and performance is the corporate governance theory as discussed by Shleifer and Vishny (1997). The author noted that government-owned firms are technically controlled by the public while run by political bureaucrats with concentrated control rights but no significant cash flow rights. These political bureaucrats have conflicting interests with those of the taxpayers as their decisions are based on political interests and not on firm value maximization. Government ownership, according to this theory is, therefore, detrimental to firm performance.

The agency theory as proposed by Jensen and Meckling (1976) is also relevant in the study of government ownership and performance relationship. This theory holds that whenever there is a separation between owners and firm managers, agency cost arises. This is because of conflict of goals between owners and managers which usually extends from principal-agent conflict to principalprinciple conflict (Phung and Hoang, 2013). To reduce these conflicts, several measures have been recommended by scholars. These governance mechanisms include ownership structures (Haniffa and Hudaib, 2006). Scholars argue that institutional investors are an important corporate governance mechanism that can help improve firm performance as they have both the ability and incentive to discipline corporate managers (Ping and Wing, 2011; Alfaraih, 2012). The state as an institutional investor can, therefore, help to improve corporate governance in organisations and, therefore, help improve their performance. The state, however, is not just a shareholder but also a regulator and might, therefore, be unwilling to discipline corporate managers due to political interests.

\section{Effect of Government Ownership on Performance}

Yu (2013) studied the relationship between government ownership and firm performance focusing on Chinese non-financial Public Listed Companies (PLCs). The study used panel data regression analysis during 2003 - 2010. The results showed that government ownership had a Ushaped relationship with firm performance. The study concluded that higher levels of government ownership are superior to dispersed ownership structure because of potential government support and political connections. Cornett et al. (2009) examined how government ownership and involvement affects bank performance in Asian countries. The study used financial statements of firms in 16 Far East countries from 1989 - 2004. The 
results showed that government ownership had a negative influence on bank performance.

An investigation of ownership structure and bank performance by Kobeissi (2004) in The Middle East and North Africa (MENA) revealed that government ownership has a negative effect on firm performance. The data was collected during 2000 - 2002 periods from 249 banks in 22 countries. Another study focusing on banks in MENA countries by Farazi et al. (2011) also revealed a negative relationship between government ownership and firm performance.

In Kenya, Ongore and K'Obonyo (2011) examined the effect of selected corporate governance features on firm performance. Using primary data from 39 listed firms and employing logistic and step-wise regression analyses, the study revealed that government ownership was negatively related with firm performance. Kiruri (2013) used secondary data from 2007 - 2011 on 43 banks in Kenya and found that government ownership was negatively related with firm performance. While both studies attempt to assess the effect of government ownership on performance, they suffer from design flaws. The former is based on a survey in which respondents were asked to score on some selected corporate governance variables including government ownership. Survey respondents tend to be biased in their responses and such biases may influence study results. The later study focuses on banks only and, therefore, leaves out other sectors in the economy. Both studies include a mix of firms with and without government shareholding in their analysis and no attempt is made to differentiate the two. Further, none of these studies measures the extent of government shareholding in firms. We address these design flaws by focusing only on listed firms that have government shareholding. Further, we use panel data and, therefore, employ panel data techniques to analyze data.

\section{Methodology}

\section{Sample and Data}

The Nairobi Securities Exchange currently has 64 listed companies of which only 10 have government shareholding. We gathered financial data from 2003 through to 2013 for all the ten firms. The data was gathered from various sources as there is no one-stop source of information for all the annual reports of listed firms in Kenya. We, therefore, got annual reports for each of these companies for the period under study from respective company websites, the Capital Markets Authority (CMA) website, and from an online repository for annual reports www.africanfinancials.com which contains most annual reports of companies listed on African stock exchanges. This data provided an unbalanced panel data as we could not find annual reports for some of the companies either because they were not available anywhere within our sources or that they were not already listed sometime after 2003. We, therefore, have a total of 102 firm-year observations in the final sample. The companies are Safaricom (9 firm-year observations), National Bank of Kenya (10 firm-year observations), Mumias Sugar Company (10 firm-year observations), Kenya Re-insurance (10 firm-year observations), Kenya Power (11 firm-year observations), KENGEN (11 firm-year observations), Kenya Airways (11 firm-year observations), Kenya Commercial Bank (10 firm-year observations), Housing Finance (10 firm-year observations), and East African Portland Cement Company (10 firm-year observations).

\section{Measurement of Variables}

Studies in corporate governance that have related government ownership to firm performance have measured performance using either market-based performance indicators or accounting-based performance indicators. The accounting-based performance indicators include return on assets (ROA), return on equity (ROE), return on sales (ROS), ratio of earnings before interest minus taxes to assets (REITA), and earnings before interest and tax (EBIT) among other such ratios. Marketbased indicators include market to book ratio (MBR), share returns, firm efficiency, and Tobin's $Q$ among other indicators. Since the use of ROA is widespread as an accounting-based performance measure, we include it in our study as a dependent variable. We also use Tobin's $Q$ as a market-based indicator as it is less noisy and, therefore, better than $\operatorname{MBR}(\mathrm{Yu}, 2003)$ or other marketbased indicators. We measure ROA as the ratio of profit after tax to total assets while Tobin's $Q$ is measured as the ratio of the sum of market of equity and market value of market value of debt to total assets. Tobin's Q and ROA have been used by scholars before as dependent variables in studies relating corporate governance to firm performance (Jiang et al. 2004; Hess et al. 2010; Yu, 2013). Government ownership has been measured differently by different scholars. Ongore and K'Obonyo (2011) measure government ownership as a dummy variable while Kiruri (2013) use the number of shares held by the government as the government shareholding. Yu (2013) measured it as the percentage of government ownership. We find this measure more relevant to our study as we seek to show that the proportion of government shareholding in a firm influences its financial performance as opposed to the number of shares held by the government or the fact that the government owns shares in a firm or not. Since previous studies have showed that government ownership has a quadratic function with firm performance $(\mathrm{Yu}, 2013$; Tian and Estrin, 2008), we also include the quadratic term of government ownership in our model.

\section{Model Specification and Estimation Methods}

In this study, we have built the regression model specification using corporate governance and firm performance literature. Our main aim is to examine the relationship between government ownership and firm performance but we also include firm size as a control variable in the model. Firm size has been found to influence performance in previous studies. We have employed panel 
data regressions to examine the relationship between government ownership and performance. We use the following econometric model to test this relationship:

$\operatorname{perf}_{i t}=\beta_{1} \operatorname{govprop}_{i t}+\beta_{2} \operatorname{govprop}_{i t}+\beta_{3} \operatorname{size}_{i t}$

In this study, perfit represents dependent variables to measure firm performance for firm $i$ at time $t$. The dependent variables are return on assets (ROA) and Tobin's Q. The independent variable is govprop which measures government ownership. The control variable in the model is size. Since this is a panel data, firm fixed effects, industry fixed effects and year fixed effects are included in the model during analysis. A more detailed definition of these variables is shown in Table 1.

Table 1: Operationalization of Variables

\begin{tabular}{lll}
\hline Variable & Notation & Definition \\
\hline Performance & tobinq & $\begin{array}{l}\text { Tobin's Q: the ratio of the market value of } \\
\text { equity and total debts to total assets. }\end{array}$ \\
\hline roa & $\begin{array}{l}\text { Return on Assets: Profit after tax divided } \\
\text { by total assets }\end{array}$ \\
$\begin{array}{l}\text { Government } \\
\text { Ownership }\end{array}$ & govprop & $\begin{array}{l}\text { Proportion of ordinary shares owned by } \\
\text { government in a firm }\end{array}$ \\
\hline Size & lnassets & Logarithmic transformation of total assets \\
\hline
\end{tabular}

\section{EMPIRICAL ANALYSIS}

\section{Descriptive Statistics}

The final sample had 10 firms that are listed on the Nairobi Securities Exchange and have government ownership in terms of the Cabinet Secretary in the Ministry of Finance (now the National Treasury) holding shares on behalf of the government. Table 2 shows the summary descriptive statistics on the variables used in the study. ROA ranges from $-9.7 \%$ to $21.3 \%$ with a mean ROA of $4.5 \%$ and a standard deviation of $5.5 \%$. Tobin's Q ranges from $9.3 \%$ to $87.7 \%$ with a mean of $51.2 \%$ and a standard deviation of $26.3 \%$. Government ownership in listed firms ranges from $3.7 \%$ to $100 \%$ with a mean ownership of $36.2 \%$ and a standard deviation of $22.4 \%$.

Table 2: Summary Descriptive Statistics

\begin{tabular}{llllll}
\hline Variable & $\mathbf{N}$ & Mean & SD & Min & Max \\
\hline Return on Assets (ROA) & 102 & .0454387 & .0553813 & -.0971554 & .2129198 \\
\hline Tobin's Q & 102 & .5124093 & .2628284 & .0929673 & .8769776 \\
\hline Government Ownership & 102 & 36.22412 & 22.36328 & 3.65258 & 100 \\
\hline Size & 102 & 17.11218 & 2.687402 & 10.09638 & 23.33815 \\
\hline
\end{tabular}

\section{Correlation Matrix}

The correlation matrix is shown in Table 3 . The results show the correlations between the independent variables in the model. We have used this method to check for multicollinearity. Multicollinearity can result in numerically unstable estimates of the regression coefficients $(Y u, 2013)$. The results reveal that the correlations of each pair wise variable are low, except for Government ownership variables which is understandable given that one is a square form of the other.
Table 3: Correlation Matrix

\begin{tabular}{|c|c|c|c|}
\hline & 1 & 2 & 3 \\
\hline Government Ownership & 1.0000 & & \\
\hline Government Ownership ${ }^{2}$ & 0.9565 & 1.0000 & \\
\hline Size & 0.5359 & 0.5720 & 1.0000 \\
\hline
\end{tabular}

We also use Wooldridge's (2002) method as summarised by Drukker (2003) to test for auto-correlation. The null hypothesis of no serial correlation was strongly rejected. Further, the test results show that the first differences of these variables are not serially correlated. We then test for heteroskedasticity using the suggestion by Wiggins and Poi (2001) for testing panel-level heteroskedasticity and find the presence of panel-level heteroskedasticity. Currently, there are methods that can be used to model and account for serial correlations, heteroskedasticity, and nonstationarity problems in panel data. We, therefore, employ the Feasible Generalised Least Square (FGLS) model in first difference to account for both heteroskedasticity and nonstationarity while also modifying the model to account for serial correlation. We test for the existence of unit roots in the panel data. We use Choi's (2001) proposal on testing for unit roots in panel data using Fisher's test. The results in Table IV show that except for Tobin's Q, all the other variables are non-stationary.

Table 4: Panel Unit-Root Test Results

\begin{tabular}{lcl}
\hline Variable & Fisher's P-value & Decision \\
\hline Tobin's Q & $<.05$ & $\begin{array}{l}\text { Reject null; } \\
\text { data is stationary }\end{array}$ \\
\hline ROA & $>.05$ & $\begin{array}{l}\text { Accept null; } \\
\text { data is non-stationary }\end{array}$ \\
\hline Government ownership & $>.05$ & $\begin{array}{l}\text { Accept null; } \\
\text { data is non-stationary }\end{array}$ \\
\hline Government ownership2 & $>.05$ & $\begin{array}{l}\text { Accept null; } \\
\text { data is non-stationary }\end{array}$ \\
\hline Size & $>.05$ & $\begin{array}{l}\text { Accept null; } \\
\text { data is non-stationary }\end{array}$ \\
\hline
\end{tabular}

\section{Regression Results}

Table 5 shows the results of FGLS regression analysis. The Tobin's Q model shows that government ownership has a positive but insignificant relationship with the financial performance of firms at lower levels of ownership, $p>.05$. As the levels of government shareholding rises in listed firms (to about $41 \%$, the relationship is negative and highly significant, $p<.05$. In this model, size was negative but insignificant, $p<.05$.

Table 5: Effect of Government Ownership on Performance

\begin{tabular}{lll}
\hline Variable & Tobin's Q & ROA \\
\hline Government Ownership & 0.001628 & 0.000651 \\
\hline Government Ownership2 & $-0.000020^{*}$ & -0.000006 \\
\hline Size & -0.002417 & 0.002680 \\
\hline cons & $0.010288^{* *}$ & $0.001543^{* *}$ \\
\hline $\mathrm{N}$ & 92 & 92
\end{tabular}

Legend: ${ }^{*} \mathrm{p}<0.05 ;{ }^{* *} \mathrm{p}<0.01 ;{ }^{* * *} \mathrm{p}<0.001$ 
The ROA model showed a positive but insignificant relationship between government ownership and firm performance at lower levels of government shareholding, $p>.05$. Further, the results showed that as the levels of government shareholding rose, the relationship was negative but insignificant, $\mathrm{p}>.05$. Size of the firm was positive but insignificant, $\mathrm{p}<.05$. Both models used the FGLS model in first difference.

\section{Results AND Discussion}

The results show that the relationship between government ownership and performance of firms in Kenya is nonlinear. It is revealed that when the proportion of government ownership in listed firms is relatively small, there is no relationship between ownership and performance as measured by both ROA and Tobin's Q. As government ownership rises to about $41 \%$, the relationship with performance as measured by Tobin's $Q$ is negative and significant. These results mirror perfectly those of Wei (2007) in China who noted that government ownership was insignificantly related with performance at low levels of ownership but as the ownership rose to $50 \%$, the relationship was negative and significant.

The results differ from those of Ongore and K'Obonyo (2011) who found a negative relationship between firm performance and government ownership in Kenya. The difference can be explained by the differences in the design. While we employ a panel data technique to examine the relationship between government ownership and performance, the previous study used a survey where primary data was collected and, therefore, cannot provide a true state of affairs as far as how the levels of government ownership affect firm performance. Our methodology allows us to test the effect of increasing government shareholding in firms. This was not the case with previous studies done on Kenya.

\section{Conclusion And Policy Implications}

We have applied panel data regression techniques to examine the relationship between government ownership and performance of listed firms in Kenya. We have used 102 firm-year observations during 2003 - 2013. The results show that there is no relationship between government ownership and firm performance at lower levels of government shareholding in firms but as the shareholding increases to $41 \%$, the relationship is negative for Tobin's Q but remains non-related with ROA.

Therefore, for firms where government ownership is Kenya is very large, like firms in the energy sector, performance is negatively related with the level of shareholding. These are strategic sectors of the economy in which the government has retained a large shareholding and, therefore, the concentrated ownership in these firms has failed in effectively monitoring the management and, therefore, led to poor performance. This may explain why government ownership has been suggested by scholars as leading to greater inefficiency in firms and, therefore, poor performance.

Further, for firms where the level of shareholding is below $41 \%$, there is no relationship. Thus, while it may not be fit to call for the government to offload its shares in firms in which it has large shares, it may be practical for the government to shed off some of it and maintain its ownership below $41 \%$ in these firms. This way, it can still maintain control in the firms that belong to strategic industries such as the energy while not negatively influencing their performance.

\section{REFERENCES}

Alfaraih, M., Alanezi, F., \& Almujamed, H. (2012), “The Influence of Institutional and Government Ownership on Firm Performance: Evidence from Kuwait", International Business Research; 5(10), 192 - 200.

Brink, A. (2010), “Enlightened Corporate Governance: Specific Investments by Employees as Legitimisation for Residual Claims", Journal of Business Ethics, 93, 641 - 651.

Choi, S. B., Park, B. I. \& Hong, P. (2012), “Does Ownership Structure Matter for Firm Technological Innovation Performance? The Case of Korean Firms", Corporate Governance: An International Review, 20(3), 267-288.

Cornett, M.M., Guo, L., Khaksari, S., \& Tehranian, H. (2008), "The Impact of State Ownership on Performance Differences in Privately-Owned versus State-Owned Banks: An International Comparison", Journal of Financial Intermediation, Forthcoming.

Drukker, D.M. (2003), “Testing for serial correlation in linear panel-data models", Stata Journal, 3, 168 - 177.

Fama, E.F., \& Jensen, M.C., (1983), "Separation of ownership and control", Journal of Law and Economics, 26 (2), 301-325.

Haniffa, R., \& Hudaib, M. (2006), “Corporate Governance Structure and Performance of Malaysian Listed Companies", Journal of Business Finance and Accounting, 33(78), 1034-1062.

Hess, K., Gunasekarage, A., \& Hovey, M. (2010), “Statedominant and non-state-dominant ownership concentration and firm performance: evidence from China", International Journal of Managerial Finance, 6 (4) (2010), 264-289.

Hovey, M., Li, L. \& Naughton, T (2003), "The relationship between valuation and ownership of listed firms in China", Corporate Governance: An International Review, 11 (2), 112-122.

Jensen, M., \& Meckling, W. (1976), “Theory of the Firm: Managerial Behavior, Agency Costs and Ownership Structure", Journal of Financial Economics, 3(3), 305-360.

Jiang, B.B., Laurenceson, J. \& Tang, K.K. (2008), "Share reform and the performance of China's listed companies", China Economic Review, 19 (3), 489-501.

Kiruri, R.M. (2013), "The effects of ownership structure on bank profitability in Kenya, European", Journal of Management Sciences and Economics, 1(2), 116-127.

Kobeissi, N., (2004), "Ownership structure and bank performance: evidence from the Middle East and North Africa". Working Paper presented in 2004 at the Economic Research Forum Conference in Beirut- Lebanon.

Ongore, V.O. \& K'Obonyo, P.O. (2011), "Effects of Selected Corporate Governance Characteristics on Firm Performance: Empirical Evidence from Kenya", International Journal of Economics and Financial Issues, 1(3), 99-122.

Phung, D.N. \& Hoang, T.P.T. (2013), “Corporate Ownership and Firm Performance in Emerging Market: A Study of Vietnamese Listed Firms", Proceedings of World Business and 
Social Science Research Conference 24-25 October, 2013, Novotel Bangkok on Siam Square, Bangkok, Thailand.

Ping, Z., \& Wing, C. (2011), “Corporate Governance: A Summary Review on Different Theory Approaches", International Research Journal of Finance and Economics, (68), 7-13.

Saleh, N.M., Rahman, M.R.C.A. \& Hassan, M.S. (2009), "Ownership Structure and Intellectual Capital Performance in Malaysia", Asian Academy of Management Journal of Accounting and Finance, 5(1), 1-29.

Sun, Q., Tong, W.H.S., \& Tong, J. (2002), “How does government ownership affect firm performance? Evidence from China's privatization experience", Journal of Business Finance and Accounting, 29 (1-2), 1-27.

Tian, L.H. \& Estrin, S. (2008), "Retained shareholding in Chinese PLCs: does government ownership always reduce corporate value?" Journal of Comparative Economics, 36 (1), 74-89.
Wei, G., (2007), "Ownership structure, corporate governance and company performance in China", Asia Pacific Business Review, 13 (4), 519-545.

Wiggins, V. \& Poi, B. (2001), “Testing for panel-level heteroskedasticity and autocorrelation" [Online] http://www.stata.com/support/faqs/statistics/panellevel-heteroskedasticity-and-autocorrelation/ (Accessed March 20, 2015).

Wooldridge, J.M. (2002), Econometric Analysis of Cross Section and Panel Data, MIT Press, Cambridge, MA.

$\mathrm{Yu}$, M. (2013), "State ownership and firm performance: Empirical evidence from Chinese listed companies", China Journal of Accounting Research, 6(2), 75-87.

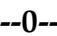

